The highest fetal cell count found in the maternal circulation was 14 per 150,000 , equivalent to approximately $0.7 \mathrm{ml}$ of fetal blood, an antigenic dose sufficient to produce primary immunization (Zipursky et al., 1965). Evidence of $\mathrm{Rh}$ isoimmunization after tubal pregnancy with a severely affected infant has been repurted in a single case (Aborjaily, 1969). We have seen a similar patient who developed an $\mathrm{Rh}$ antibody titre of $1 / 64$ in her second pregnancy, a previous tubal pregnancy having ended in intraperitoneal rupture. The baby was born jaundiced and required two exchange transfusions for hyperbilirubinaemia associated with a Coombs-positive haemolytic anaemia. As the antibody response to an antigen is dose-dependent the high $R h$ titre in these two immunized patients and the severity of the $\mathrm{Rh}$ disease in the infants suggest that the amount of fetal blood which had passed into the maternal circulation must have been relatively large.

The significant incidence of fetomaternal haemorrhage recorded in this study indicates that all $\mathrm{Rh}$-negative women with ruptured tubal pregnancies require prophylactic $\mathbf{R h}$ immunoglobulin. We also suggest that in such cases the peritoneal blood should be aspirated completely at laparotomy whenever possible so as to remove the fetal blood cells which may be a source of antigen and may produce immunization if left in situ. The practice of transfusing a patient with her own blood recovered from the peritoneal cavity should be avoided if she is Rh-negative.

We thank Professor J. Metz for his helpful criticism and advice; the director, South African Institute for Medical Research, for facilities to carry out this study; Professor L. van Dongen, Dr. A. Rubin, and the staff of the obstetrics and gynaecology department of the Baragwanath Hospital for allowing us to study patients under their care; and Dr. C. Kniep for permission to make this report. Due acknowledgement is made to the Atomic Energy Board and South African Medical Research Council for help and support enabling the research to be undertaken.

\section{References}

Aboriaily, A. N. (1969). New England fournal of Medicine, 281, 1076.

Bradley, T. B., jun., Brauner, J. N., and Conley, C. L. (1961). Bulletin of the fohns Hopkins Hospital, 108, 1242.

Clausen, J. (1938). Acta Pathologica et Microbiologica Scandinavica, Suppl. No. $37, p$. 134.

Cohen, R., and Zuelzer, W. W. (1964). Vox Sanguins, 9, 75.

Combined Study from Centres in England and Baltimore (1971). British Medical fournal, 2, 607.

Freda, V. J., Gorman, J. G., Galen, R. S., and Treacy, N. (1970). Lancet, 2,

Hedenstedt, S. (1947). Acta Chirurgica Scandinavica, 95, Suppl. No. 128,

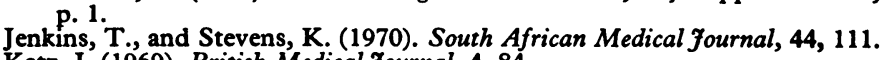
Katz, J. (1969). British Medical Fournal, 4, 84.

Kleihauer, E., Braun, H., and Betke, K. (1957). Klinische Wochenschrift, 35, 637.

Matthews, C. D., and Matthews, A. E. B. (1969). Lancet, 1, 694.

Mollison, P. L. (1968). British fournal of Haematology, 14, 1 .

Murray, S., and Barron, S. L. (1971). British Medical fournal, 3, 90.

Olivia, J., and Myerson, R. M. (1961). American Fournal of the Medical Sciences, 241, 215 .

Sullivan, J. F., and Jennings, E. R. (1966). fournal of Clinical Pathology, 46, 36.

Tepper, V., and Verso, M. L. (1964). Medical fournal of Australia, 2, 585. Waite, M. E., Colucci, D. D., and Glaser, J. (1956). American Yournal of Diseases of Children, 91, 561 .

Woodrow, J. C., et al. (1965). British Medical fournal, 1, 279

Woodrow, J. C., and Finn, R. (1966). British fournal of Haematology, 12, 297.

Woodrow, J. C., Clarke, C. A., McConnell, R. B., Towers, S. H., and Donohoe, W. T. A. (1971). British Medical fournal, 2, 610.

Zipursky, A., and Israels, L. G. (1967). Canadian Medical Association fournal, $97,1245$.

Zipursky, A., Pollock, J., Neelands, P., Chown, B., and Israels, L. G. (1963). Lancet, 2, 493.

Zipursky, A., Pollock, J., Chown, B., and Israels, L. G. (1965). In Birth Defects, Original Article Series, ed. D. Bergsma, Vol. 1, p. 84. New York, National Association, March of Dimes.

\title{
Galactorrhoea: Successful Treatment with Reduction of Plasma Prolactin Levels by Brom-ergocryptine
}

\author{
G. M. BESSER, LYNNE PARKE, C. R. W. EDWARDS, ISABEL A. FORSYTH, A. S. MCNEILLY
}

British Medical fournal, 1972, 3, 669-672

\section{Summary}

In five patients with inappropriate lactation and amenorrhoea or impotence brom-ergocryptine was found to suppress the lactation and to diminish the raised plasma prolactin levels. The responses to treatment suggest that there may be an inverse relationship between prolactin secretion and gonadotrophin secretion in man.

\section{Introduction}

In most patients inappropriate lactation is accompanied by raised plasma levels of prolactin. Inappropriate lactation may be due to hypothalamic or pituitary disease, or to the action of

St. Bartholomew's Hospital, London E.C.1

G. M. BESSER, M.D., M.R.C.P., Senior Lecturer in Endocrinology

C. R. W. EDWARDS, M.B., M.R.C.P., Lecturer in Medicine

A. S. MCNEILLY, B.SC., PH.D., Research Lecturer in Chemical Pathology

National Institute for Research in Dairying, Shinfield, Berks.

LYNNE PARKE, B.sc., Scientific Officer

ISABEL A. FORSYTH, M.A., D.PHIL., Principal Scientific Officer psychoactive drugs (Forsyth et al., 1971; Kleinberg and Frantz, 1971; Besser and Edwards, 1972). This hyperprolactinaemia is usually accompanied by reduced plasma gonadotrophin levels and amenorrhoea in women and impotence in men. There may be a reciprocal mechanism controlling secretion of prolactin and the gonadotrophins (Ben-David et al., 1971; Kamberi, et al., 1971a, 1971b). Pathological galactorrhoea is difficult to treat, though if it follows medication with the contraceptive pill it may occasionally respond to clomiphene. We now report the use of the ergot alkaloid 2-Br-alpha-ergocryptine (referred to in this paper as brom-ergocryptine) in five patients with galactorrhoea and show that it rapidly lowers plasma prolactin levels leading to cessation of lactation and, with the exception of a patient who had undergone partial hypophysectomy, to resumption of normal gonadal function with menstruation or potency. Lutterbeck et al. (1971) previously reported preliminary clinical studies and termination of galactorrhoea in three non-puerperal women on brom-ergocryptine, and Varga et al. (1972) showed that it inhibits puerperal lactation.

\section{Methods}

Prolactin Bioassay.-The lactogenic response obtained in cultured mammary tissue of pseudopregnant rabbits was used 
as an index of the lactogenic activity in the plasma samples. Details of the methods were given by Forsyth and Myres (1971) and Forsyth et al. (1971). This assay responds only to prolactin, placental lactogen, and primate growth hormone. In every plasma sample assayed for prolactin the immunoreactive growth hormone levels were also measured and in each case were shown to be too low to register in the prolactin bioassay. The lactogenic activity of the plasma samples was therefore due to their prolactin content. The assay is only semiquantitative and the plasma prolactin concentration was estimated by comparison with the activities of known amounts of standard sheep prolactin (NH-P-S6, $25 \mathrm{IU} / \mathrm{mg}$ ); results are expressed in $\mathrm{ng} / \mathrm{ml}$ ovine prolactin equivalent. The sensitivity of this assay in plasma is about $50 \mathrm{ng} / \mathrm{ml}$, and plasma from normal control subjects shows no activity (Forsyth et al. 1971). Brom-ergocryptine itself and any metabolites contained in plasma from patients on long-term therapy were shown not to interfere with the prolactin bioassay.

Prolactin Radioimmunoassay.-This assay was performed as described by Hwang et al. (1971) using antiserum raised against human growth hormone and ${ }^{125} \mathrm{I}$-labelled human prolactin. Growth hormone concentrations less than $1,000 \mathrm{ng} / \mathrm{ml}$ do not cross-react in this system. The minimum detectable level of prolactin in plasma was $22 \mathrm{ng} / \mathrm{ml}$, and in normal subjects concentrations are below this level.

Other Hormone Assays.-Plasma fluorogenic corticosteroids, serum immunoreactive growth hormone $(\mathrm{GH})$, thyrotrophin (TSH), luteinizing hormone (LH), protein bound iodine (P.B.I.), and T-3 uptake were measured by standard techniques (details of the methods used were given by Hall et al., 1972, and Besser et al., 1972) and plasma 17-hydroxyandrogens (17-OHA) as a measure of testosterone concentration by the technique of Anderson (1970).

Clomiphene Stimulation Tests.-Doses of 150 or $200 \mathrm{mg}$ per day of clomiphene were given and the plasma LH response was followed over 10 days. The lower dose was used in the female patients. In normal subjects the LH levels rise outside the normal range during clomiphene administration (Anderson et $a l ., 1972$ ). In this $\mathrm{LH}$ assay the normal range is $0.8-4.5 \mathrm{mU} / \mathrm{ml}$ in males and in females during the follicular phase of their menstrual cycle.

Insulin tolerance tests were performed using $0 \cdot 15 \mathrm{U} / \mathrm{kg}$ soluble insulin intravenously, with measurement of the $\mathrm{GH}$, plasma corticosteroid, and blood sugar responses. In each case the blood sugar fell to less than $40 \mathrm{mg} / 100 \mathrm{ml}$ and the patient was seen to sweat.

Thyrotrophin-releasing hormone (TRH) tests were performed according to Ormston et al. (1971), sampling for serum TSH at 0,20 , and 60 minutes after the intravenous injection of $200 \mu \mathrm{g}$ TRH.

\section{Patients}

No patient had evidence of hepatic or renal disease and none gave a history of taking a drug likely to cause galactorrhoea (Besser and Edwards, 1972). All patients were euthyroid, had normal visual fields, and in all the serum GH level was suppressed to less than $5 \mathrm{ng} / \mathrm{ml}$ during an oral glucose tolerance test, thus excluding a diagnosis of acromegaly. No patient had clinical or biochemical evidence of Cushing's syndrome. The major clinical and endocrine findings before treatment are shown in Table I. Additional features are given below.

Case 1.- A man with bilateral mild gynaecomastia and copious lactation, a female distribution of body fat, and normal body hair. P.B.I. $4.7 \mu \mathrm{g} / 100 \mathrm{ml}, \mathrm{T}-3 \mathrm{resin} 1.01$, plasma 17-OHA 8.5 $\mathrm{ng} / \mathrm{ml}$ (normal range $4 \cdot 9-21.5 \mathrm{ng} / \mathrm{ml}$ ). TRH test: serum TSH level at $0 \mathrm{~min} 2.9,20 \mathrm{~min} 15.0,60 \mathrm{~min} 10.6 \mu \mathrm{U} / \mathrm{ml}$ (normal response). Urine total oestrogen excretion (Searle's) 5 and 7 $\mu \mathrm{g} / 24 \mathrm{hr}$ (normal), air encephalogram normal.

Case 2.-Nulliparous woman. P.B.I. $4.9 \mu \mathrm{g} / 100 \mathrm{ml}, \mathrm{T}-3$ resin 1.09, urinary total oestrogens 11 and $29 \mu \mathrm{g} / 24 \mathrm{hr}$. TRH test: serum TSH level at $0 \mathrm{~min} 2 \cdot 1,20 \mathrm{~min} 12 \cdot 0,60 \mathrm{~min} 6.8 \mu \mathrm{U} / \mathrm{ml}$ (normal response). Air encephalogram normal.

Case 3.-A woman with two past pregnancies, five and six years before. She had received an oral contraceptive for three years but the galactorrhoea and amenorrhoea did not start until 11 months after this had been stopped. P.B.I. $7 \cdot 0 \mu \mathrm{g} / 100 \mathrm{ml}$, T-3 resin 1.02 TRH test: serum TSH at $0 \mathrm{~min} 1.9,20 \mathrm{~min}$ $7 \cdot 5,60 \mathrm{~min} 6.0 \mu \mathrm{U} / \mathrm{ml}$ (normal response). Urinary total oestrogens 10 and $14 \mu \mathrm{g} / 24 \mathrm{hr}$.

Case 4.-A man with profuse bilateral galactorrhoea and mild gynaecomastia which developed three months after partial hypophysectomy for a chromophobe adenoma of the pituitary. He was taking oral hydrocortisone replacement $(30 \mathrm{mg} /$ day $)$. P.B.I. $4.7 \mu \mathrm{g} / 100 \mathrm{ml}$, T-3 resin 1.01 , plasma $\mathrm{LH} 0.6 \mathrm{mU} / \mathrm{ml}$, plasma 17-OHA $5.3 \mathrm{ng} / \mathrm{ml}$. TRH test: serum TSH at $0 \mathrm{~min} 1 \cdot 0,20 \mathrm{~min}$ 3.3, $60 \mathrm{~min} 2.7 \mu \mathrm{U} / \mathrm{ml}$ (impaired), fasting serum $\mathrm{GH}<2 \mathrm{ng} / \mathrm{ml}$ on several occasions. He had been impotent for 18 months before operation and did not need to shave.

Case 5.-Nulliparous woman with irregular periods for one year after stopping contraceptive pill followed by four years' complete amenorrhoea. Bilateral galactorrhoea noticed two months after stopping Ortho-Novin. P.B.I. $6.0 \mu \mathrm{g} / 100 \mathrm{ml}$, resin T-3 1.12, urinary total oestrogens 5 and $14 \mu \mathrm{g} / 24 \mathrm{hr}$, plasma 17-OHA $0.9 \mathrm{ng} / \mathrm{ml}$ (normal female level).

Prolactin Levels.-Plasma prolactin levels measured by bioassay and radioimmunoassay before treatment were raised in each patient (Figs. 1-3).

Treatment.- Treatment with brom-ergocryptine was started with $3 \mathrm{mg} /$ day increasing after two days to $6 \mathrm{mg} /$ day. In cases 4 and 5 the dose was further increased to $9 \mathrm{mg} /$ day after six and two weeks respectively as the galactorrhoea had not completely subsided.

\section{Results}

Side Effects.-One patient complained of heartburn and one of anorexia. These symptoms disappeared when the capsules were taken with food. No other side effects were seen and there were no changes in haemoglobin, leucocytes, platelets, liver function tests, blood urea, or electrolytes.

Effects on Galactorrhoea and Amenorrhoea.-The milk flow lessened within two weeks of treatment in each case and had completely disappeared after one to 12 weeks. Regular menstruation resumed in the women between three and six weeks after starting brom-ergocryptine and was maintained throughout

TABLE I-Major Clinical and Endocrine Findings before Treatment

\begin{tabular}{|c|c|c|c|c|c|c|c|c|}
\hline \multirow{2}{*}{$\begin{array}{l}\text { Case } \\
\text { No. }\end{array}$} & \multirow{2}{*}{$\begin{array}{l}\text { Sex } \\
\text { and } \\
\text { Age }\end{array}$} & \multicolumn{3}{|c|}{ Duration of Disorder } & \multirow{2}{*}{$\begin{array}{l}\text { Plasma LH Response } \\
\text { to Clomiphene* } \\
(\mathrm{mU} / \mathrm{ml})\end{array}$} & \multicolumn{2}{|c|}{ Response to Hypoglycaemia } & \multirow{2}{*}{$\begin{array}{c}\text { Pituitary } \\
\text { Fossa on } \\
\text { Radiography }\end{array}$} \\
\hline & & Galactorrhoea & Amenorrhoea & Impotence & & $\begin{array}{l}\text { Plasma Corticosteroids } \dagger \\
(\mu \mathrm{g} / 100 \mathrm{ml})\end{array}$ & $\underset{(\mathbf{n g} / \mathbf{m l})}{\mathbf{G H}}$ & \\
\hline $\begin{array}{l}1 \\
2 \\
3 \\
4 \\
5\end{array}$ & $\begin{array}{l}\text { M. } 25 \\
\text { F. } 25 \\
\text { F. } 25 \\
\text { M. } 36 \\
\text { F. } 27\end{array}$ & $\begin{array}{l}18 \text { months } \\
6 \text { months } \\
12 \text { months } \\
3 \text { months } \\
5 \text { years }\end{array}$ & $\begin{array}{l}6 \text { years } \\
11 \text { months } \\
4 \text { years }\end{array}$ & 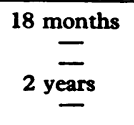 & $\begin{array}{l}\text { Impaired, } 2.4 \text { rising to } 3.4 \\
\text { Normal, } 1.5 \text { rising to } 6.2 \\
\text { Impaired, } 2.0 \text { rising to } 3.5 \\
\text { Normal, } 4.4 \text { rising to } 5.3\end{array}$ & $\begin{array}{l}\text { Normal, } 8 \text { rising to } 25 \\
\text { Normal, } 10 \text { rising to } 29 \\
\text { Norma, } 18 \text { rising to } 26 \\
\text { On replacement } \\
\text { Normal, } 17 \text { rising to } 29\end{array}$ & $\begin{array}{l}\text { Impaired maximum level } 11 \\
\text { Impaired maximum level } 17 \\
\text { Impaired maximum level } 12 \\
\text { Normal maximum level } 43\end{array}$ & $\begin{array}{l}\text { Abnormal } \\
\text { Enlarged } \\
\text { Enlarged } \\
\text { Enlarged } \\
\text { Normal }\end{array}$ \\
\hline
\end{tabular}

* Normal range for serum LH : 0.8 to $4.5 \mathrm{mU} / \mathrm{ml}$ in males and females in follicular phase of cycle, rising outside the normal range after 7 to 10 days of clomiphene (standard LH; M.R.C. 68/40)

t Normal response during insulin tolerance test $(0 \cdot 15 \mathrm{U} / \mathrm{kg}$ ) : plasma corticosteroids rise to above $21 \mu \mathrm{g} / 100 \mathrm{ml}$, serum GH to above $20 \mathrm{ng} / \mathrm{ml}$ (standard GH; $\mathrm{M} . \mathrm{R} . \mathrm{C} .69 / 46)$. † Assymetric fossa suggestive of tumour but not frankly enlarged. 


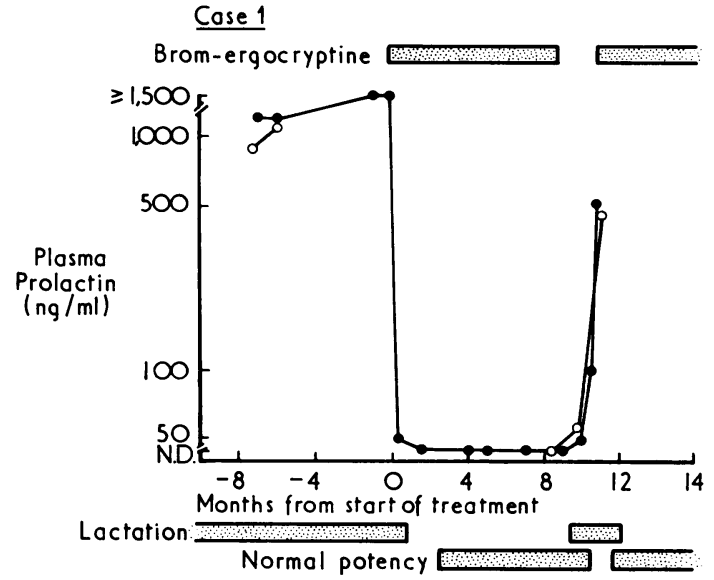

FIG. 1-Plasma prolactin concentrations measured by bioassay (O) and radioimmunoassay $(O)$ in a man with galactorrhoea during treatment with brom-ergocryptine. Changes in lactation and potency are also shown N.D. = Not detectable in assay-for example, prolactin levels $<50 \mathrm{ng} / \mathrm{ml}$ by bioassay, $<22 \mathrm{ug} / \mathrm{ml}$ by radioimmunoassay).

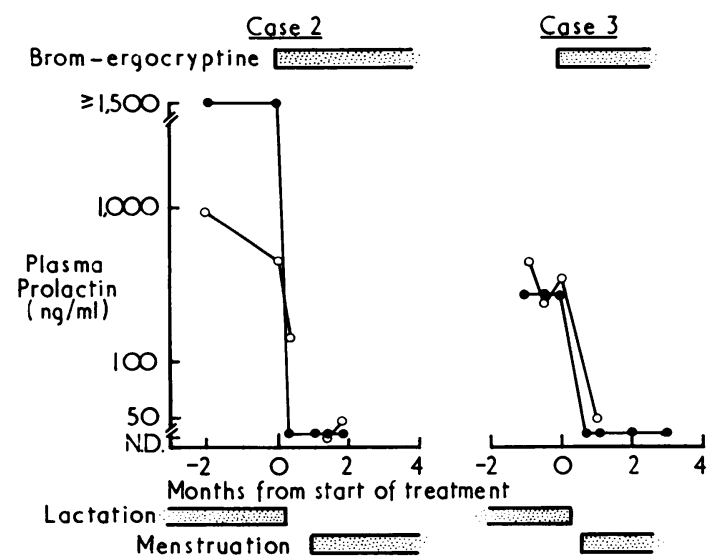

FIG. 2-Plasma prolactin concentrations measured by bioassay $(O)$ and radioFIG. 2-Plasma prolactin concentrations measured by bioassay $(O)$ and radioimmunoassay $(O)$ in two women with galactorrhoea and enlarged pituitary menstruation are also shown. N.D. = Not detectable in assay.
mens during treatment with brom-ergocryptine. Changes in

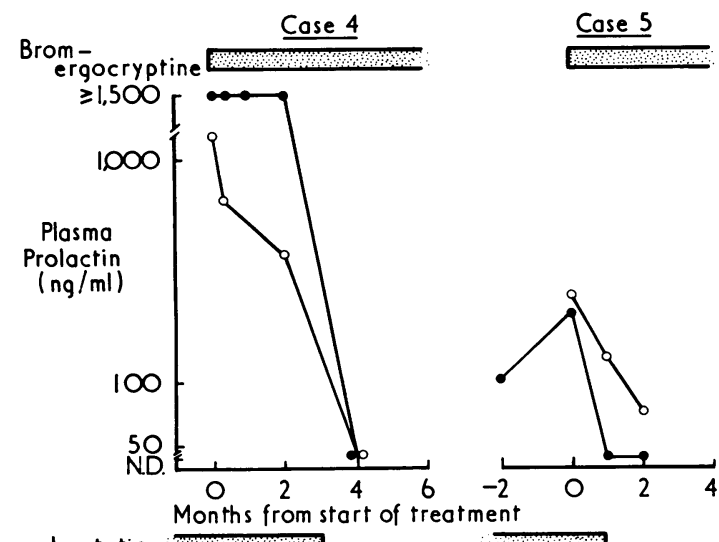

Lactation

Impotent throughout $\longrightarrow$ Menstruation

FIG. 3-Plasma prolactin concentrations measured by bioassay (O) and radioimmunoassay $(O)$ during treatment with brom-ergocryptine in a partially hypophysectomized man with galactorrhoea (case 4) and a woman who developed galactorrhoea and amenorrhoea after oral contraceptive medication (Case 5). The changes in lactation and menstruation are shown; the man remained impotent. N.D. = Not detectable in assay.

treatment. In the men potency returned in Case 1 in four weeks, but Case 4 remained impotent throughout treatment. Details of the changes are given in Table II.

Plasma prolactin levels fell rapidly during treatment in each case and remained low as long as treatment was continued (Figs.
TABLE II-Effects of Treatment with Brom-ergocryptine

\begin{tabular}{c|c|c|c|c}
\hline \multirow{2}{*}{$\begin{array}{c}\text { Case } \\
\text { No. }\end{array}$} & \multicolumn{2}{|c|}{$\begin{array}{c}\text { Weeks to Resumption } \\
\text { of Normal }\end{array}$} & $\begin{array}{c}\text { Weeks to Disappearance } \\
\text { of Galactorrhoea }\end{array}$ & $\begin{array}{c}\text { Maintenance Dose of } \\
\text { Brom-ergocryptine } \\
\text { (mg/day) }\end{array}$ \\
\cline { 2 - 3 } & Menses & Potency & & 6 \\
\hline 1 & - & $4^{*}$ & 8 & 6 \\
2 & 6 & - & 1 & 6 \\
4 & $\frac{3}{4}$ & Absent & 12 & 9 \\
5 & 6 & - & 4 & 9 \\
\hline
\end{tabular}

* Treatment continued 10 months then stopped; mild galactorrhoea returned within 2 weeks but became copious with return of impotence by 8 weeks.

1-3). Further details on the response to treatment in the patients are given below.

Case 1.-During the 10 months of treatment with bromergocryptine the patient's breast tissue atrophied and the body fat was redistributed in a male pattern. The plasma 17-OHA rose from 8.5 to $15.9 \mathrm{mg} / \mathrm{ml}$. Treatment $(6 \mathrm{mg} /$ day) was continued for 10 months then stopped. Mild galactorrhoea had returned two weeks later and was copious by two months, when impotence had also returned. During this time plasma prolactin levels rose (Fig. 1). Within three weeks of restarting brom-ergocryptine galactorrhoea had stopped and potency had returned.

Case 2 and 3.-Regular menstruation without galactorrhoea continued after four and six months respectively.

Case 4.- This man's breast tissue atrophied, was non-secreting, and the body fat adopted a male distribution during the sixmonths of therapy. Nevertheless, he remained impotent, with low plasma 17-OHA levels $(3 \cdot 7 \mathrm{ng} / \mathrm{ml})$.

Case 5.- This patient had two menstrual periods and then stopped brom-ergocryptine. Menstruation had not returned during the next three months but the breasts remained non-secreting.

\section{Discussion}

A raised plasma prolactin level appears to be the feature common to the symptoms of galactorrhoea and amenorrhoea or impotence whether due to a pituitary or hypothalamic tumour or to exposure to tranquillizers or oral contraceptives (Forsyth et al., 1971; Kleinberg and Frantz, 1971; Besser and Edwards, 1972). Brom-ergocryptine suppresses pathological and puerperal lactation (Lutterbeck et al., 1971; Varga et al., 1972); we have confirmed the former observations and also now shown that the treatment is associated with suppression of the raised plasma prolactin levels whether measured by bioassay or radioimmunoassay. It is of great interest that this cessation of galactorrhoea and suppression of prolactin levels was accompanied by regular menstruation in all the women and return of potency in the man who had not had a hypophysectomy (Case 1). When this man's therapy was stopped lactation and impotence promptly returned, together with a rise in the plasma prolactin levels. The condition remitted with resumption of treatment. Menstruation continued in the patient with the post-oral-contraceptive galactorrhoea-amenorrhoea syndrome only during the two months of treatment (Case 5).

This study allowed a direct comparison of the assay of plasma prolactin concentrations by bioassay and radioimmunoassay. As the figures show, there is good agreement between the results of the two techniques in the lower ranges of values. When the levels are greatly raised, above $400 \mathrm{ng} / \mathrm{ml}$, the results of bioassay are much higher than the immunoreactive levels in some patients. The source of the dissociation is not clear.

The responses to treatment in this study suggest that there may be an inverse relation between prolactin secretion and gonadotrophin secretion in man. When serum prolactin levels are high gonadotrophin secretion is reduced, but normal gonadotrophin secretion can be achieved when the prolactin levels fall. There is evidence of a similar relation in rats (Ben-David et al., 1971; Kamberi et al., 1971a, 1971b).

Brom-ergocryptine and related compounds appear to act directly on the pituitary cells in mammals to suppress prolactin secretion (Flückiger and Wagner, 1968; Yanai and Nagasawa, 
1970; Pasteels et al., 1971; Billiter and Flückiger, 1971; Hoekfelt and Fuxe, 1972), and there is no evidence that it affects other pituitary hormones. The studies reported here show that it suppresses plasma prolactin levels in man, and it is possible that the drug is acting directly on the pituitary, since it was effective in the patient with a partial hypophysectomy whose pituitary remnant was presumably out of functional contact with the hypothalamus. The drug is effective in suppressing abnormal prolactin-dependent galactorrhoea without side effects in the doses used and at the same time it allows the return of normal menstruation or potency. While the value of oestrogen therapy to suppress puerperal lactation remains controversial it is general experience that it is ineffective in pathological lactation. Levodopa has been used, but while it has appreciable acute effects in lowering the plasma prolactin levels, its effects on the galactorrhoea are inconsistent and may not be sustained (Kleinberg et al., 1971; Friesen et al., 1972; Malarkey et al., 1971; Turkington, 1972).

Treatment with brom-ergocryptine appears to offer a definite advance in the management of patients with galactorrhoea.

We thank Mr. A. Turvey for the histological processing of the cultured mammary glands, the Endocrine Study Section, U.S. National Institutes of Health, for the supply of sheep prolactin, Dr. E. R. Evans and Sandoz Products Ltd. for the provision of brom-ergocryptine (CB 154), Dr. H. G. Friesen for the prolactin immunoassay reagents, and Dr. D. C. Anderson for the plasma 17-OHA measurements. We are grateful to the board of governors of St. Bartholomew's Hospital and the Cancer Research Campaign for financial support, and to Drs. Jean Ginsberg, J. F. Hale, and R. de Mowbray who referred patients.

\section{References}

Anderson, D. C. (1970). Clinica Chimica Acta, 29, 513.

Anderson, D. C., Marshall, J. C., Young, J. L., and Fraser, T. R. (1972). Clinical Endocrinology, 1, 127.

Ben-David, M., Danon, A., and Sulman, F. G. (1971). Fournal of Endocrinology, 51, 719 .

Besser, G. M., and Edwards, C. R. W. (1972). British Medical fournal, 2, 280. Besser, G. M. et al. (1972). British Medical fournal, 3, 267.

Billiter, E., and Flückiger, E. (1971). Experientia, 27, 464.

Flückiger, E., and Wagner, H. R. (1968). Experientia, 24, 1130.

Forsyth, I. A., and Myres, R. P. (1971). Fournal of Endocrinology, 51, 157.

Forsyth, I. A., Besser, G. M., Edwards, C. R. W., Francis, L., and Myres, R. P. (1971). British Medical fournal, 3, 225 .,

Friesen, H. G., Guyda, H., Hwang, P., Tyson, J. E., and Barbeau, A. (1972). fournal of Clinical Investigation, $51,706$.

Hall, R., Ormston, B. J., Besser, G. M., Cryer, R. J., and McKendrick, M. (1972). Lancet, 1, 759 .

Hoekfelt, T., and Fuxe, K. (1972). Neuroendocrinology, 9, 100.

Hwang, P., Guyda, H., and Friesen, H. (1971). Proceedings of the National Academy of Sciences of the United States of America, 68, 1902.

Kamberi, I. A., Mical, R. S., and Porter, J. C. (1971a). Endocrinology, 88, 1288.

Kamberi, I. A., Mical, R. S., and Porter, J. C. (1971b). Endocrinology, 88, 1294.

Kleinberg, D. L., and Frantz, A. G. (1971). Fournal of Clinical Investigation, 50, 1557.

Kleinberg, D. L., Noel, G. L., and Frantz, A. G. (1971). Fournal of Clinical Endocrinology and Metabolism, 33, 873 .

Lutterbeck, P. M., Pryor, J. S., Varga, L., and Wenner, R. (1971). British

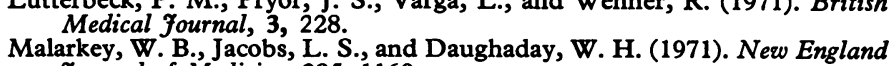
fournal of Medicine, 285, 1160 .

Ormston, B. J., Garry, R., Cryer, R. J., Besser, G. M., and Hall, R. (1971).

Lancet, 2, 10.
Pasteels, J. L., Danguy, A., Frerotte, M., and Ectors, F. (1971). Annales d'Endocrinologie, 32, 188.

Turkington, R. W. (1972). Fournal of Clinical Endocrinology and Metabolism, 34, 306 .

Varga, L., Lutterbeck, P. M., Pryor, J. S., Wenner, R., and Erb, H. (1972). Yanai, R., and Nagasawa, H. (1970). Experientia, 26, 649.

\title{
Increasing Frequency of Gall Bladder Operations in the Bristol Clinical Area
}

\author{
C. HOLLAND, K. W. HEATON
}

British Medical fournal, 1972, 3, 672-675

\begin{abstract}
Summary
In the Bristol clinical area the frequency of gall bladder operations rose by a factor of 3.4 between 1940 and 1970, the greatest increase occurring in the 1950s. The increase took place in all age groups, but was greatest in the under30 s and in men. Numerous factors affect the chance of a patient with gall stones being operated on, but a change of this magnitude suggests there has been a substantial rise in the incidence of gall stones since the second world war. This belief is supported by data from the nationwide Hospital In-patient Enquiry.
\end{abstract}

\section{Introduction}

It is commonly stated that gall stones seem to be occurring more often or that the frequency of cholecystectomy is increasing, but there are scant data to support or refute these impressions.

The only completely reliable way of assessing a change in

\footnotetext{
University of Bristol Department of Medicine, Royal Infirmary, Bristol 2

C. HOLLAND, Medical Student

K. W. HEATON, M.D., M.R.C.P., Consultant, Senior Lecturer in Medicine
}

the prevalence of gall stones would be to perform repeated cholecystographic surveys on large, random samples of the general population. No such survey has yet been completed in Great Britain. Necropsy surveys give prevalence data which presumably bear some relation to the prevalence in the general population, but there are no reports of serial necropsy surveys from the same centre covering the postwar period.

At least $98 \%$ of surgical operations on the gall bladder are performed because of gall stones (Andersson et al., 1971). Therefore the frequency of gall bladder operations should reflect the incidence of gall stones. A number of factors may influence the frequency with which patients with gall stones are brought to surgery. The variability of most of these factors is unknown or unmeasurable; some we have tried to assess.

With due regard for these uncertainties we thought it worthwhile to compute the numbers of gall bladder operations performed in the Bristol area in five years for which adequate statistics were available-that is, 1933, 1940,1950, 1960, and 1970. This paper reports our findings-namely, a pronounced rise in the frequency of gall bladder operations and a progressive change in the sex and age incidence of operated subjects since 1940.

\section{Methods}

The Bristol clinical area covers parts of southern Gloucestershire and northern Somerset as well as the city and county of Bristol. It has a population of about 800,000 (Registrar General's annual 